\title{
Suitable food plants for mass rearing of the short-horn grasshopper Oxya hyla hyla (Orthoptera: Acrididae)
}

\author{
Subhasish GHOSH, Parimalendu HALDAR and DipaK K. MANDAL*
}

\begin{abstract}
Department of Zoology, Visva-Bharati University, Santiniketan - 731 235, West Bengal, India; e-mails: dkmandal.vb@gmail.com; subhasishghsh@gmail.com; pa_haldar@yahoo.co.in
\end{abstract}

Key words. Orthoptera, Acrididae, acridid, Oxya hyla hyla, mass rearing, food plants, Sorghum halepense, Cyanodon dactylon

\begin{abstract}
Acridids could be an alternative source of protein for feeding to livestock as large numbers can be produced by rearing them on suitable food plants under optimum environmental conditions. The aim of the present study was to find a suitable food plant for the mass culture of the short-horn grasshopper Oxya hyla hyla (Serville). Food consumption and utilization, growth (growth rate, average daily growth, specific growth rate and wet weight gain), survival and life span of this insect reared on Sorghum halepense, Cyanodon dactylon and a mixture of these two plants were determined. The result revealed that the food utilization, growth and survival of this grasshopper depended on the food plant. The nymphs that were reared on C. dactylon consumed less food but had a greater efficiency of conversion of ingested food to body mass, growth performance and survival than those feed on the other two types of food. In contrast, the food consumption and utilization, growth and weight gain of adult grasshoppers was greatest when they were reared on $S$. halepense. These results indicate that of the plants used in this study $C$. dactylon is the best for rearing the nymphs and $S$. halepense for rearing the adults of Oxya hyla hyla.
\end{abstract}

\section{INTRODUCTION}

The main source of protein for human consumption in most countries is livestock. The increase in the human population has resulted in an increase in the demand for protein and a consequent increase in the production of livestock, which is constrained by the availability of protein rich feedstuffs. Insects are rich in protein, carbohydrate, fat, vitamins and minerals (Ueckert et al., 1972, Ganguly et al., 2013). Crude protein content of grasshoppers ranges between $64 \%$ and $77 \%$ depending on species (RamousElorduy et al., 1997, Wang et al., 2007; Anand et al., 2008a). Ledger (1987) suggests that Locustana pardalina (Walker) could be used as human and animal food. Many workers suggest the use of grasshoppers as poultry feed (Ramos-Elorduy et al., 1988; Wang et al., 2007; Anand et al., 2008b). Biomass production of grasshoppers is potentiality very high as they have a high reproductive potential (Lomer et al., 2001) and rapid life cycle (Ananthakrishnan et al., 1985). The locust Schistocerca produces 9 tons of biomass per year in Algeria, (Gunn, 1960) and Sphenarium sp. produces more than 10 tons of biomass per year in Mexico (Ramos-Elorduy, 1997). DeFoliart (1992) is of the opinion that to ensure a constant supply of insect biomass for adding to feedstuff for livestock we will need to mass produce certain insects. There have been several attempts to mass produce grasshoppers in controlled conditions and the results indicate that success depends on selecting the right species of grasshoppers and determining the optimum conditions in terms of space and host plants for rearing these insects. Oyxa hyla hyla is a multivoltine, polyphagous grasshopper and common pest of rice on the Indian subcontinent. Das et al. (2012a) give the optimum temperature and photoperiod for the mass production of $O$. hyla hyla and suggest this species could be a potential candidate for mass rearing. Uvarov (1966) reports that locusts fed with grasses grew faster and survived best. Sorghum halepense and Cynodon dactylon of the family poaceae, contain $15.63 \%$ and $11.60 \%$ crude protein, respectively (Ganguly et al., 2010) and are the preferred food plants of grasshoppers reared in mass culture (Haldar et al., 1995, 1998; Ganguly et al., 2010). McFarlane \& Thorsteinson (1980) report that mixed plant diets are best for Melanoplus bivittatus (Say). This observation led us to select two plants, C. dactylon and S. halepense, as food plants for rearing $O$. hyla hyla in this study. The hypothesis tested is that the multivoltine grasshopper, $O$. hyla hyla, reared on suitable food plants could be used to produce a large biomass rich in protein. The aim of the study is to determine the food consumption, efficiency of conversion of food to body mass, growth and duration of the life cycle of $O$. hyla hyla reared on two host plants: $S$. halepense and C. dactylon in order to determine which of these food plants is suitable for the mass culture of this grasshopper.

\section{MATERIAL AND METHODS}

\section{Collection of specimens}

Nymphs of Oxya hyla hyla were collected from a stock culture of this species, which has been maintained over the last three years in an insectary at the Department of Zoology, Visva-Bharati University, Santiniketan, West Bengal. This culture was established using individuals collected from agricultural crops and grassland at Santiniketan $\left(23^{\circ} 41^{\prime} \mathrm{N}, 87^{\circ} 41^{\prime} \mathrm{E} / 23^{\circ} 68^{\prime} \mathrm{N}, 87^{\circ} 68^{\prime} \mathrm{E}\right)$. The culture was kept as described by Haldar et al. (1998) under a natural photoperiod (14L: 10D) and at room temperature $\left(32 \pm 2^{\circ} \mathrm{C}\right)$.

\section{Food plants}

Soft green leaves of Cynodon dactylon Pers. were collected from the garden on the University campus. Seed of Sorghum halepense (L.) Pers. was obtained from the local market and grown in experimental plots on the campus. Young green mature and unfolded leaves were collected, weighed and the cut ends of the leaves were immersed in water in small glass vials and offered to the insects.

\footnotetext{
* Corresponding author.
} 

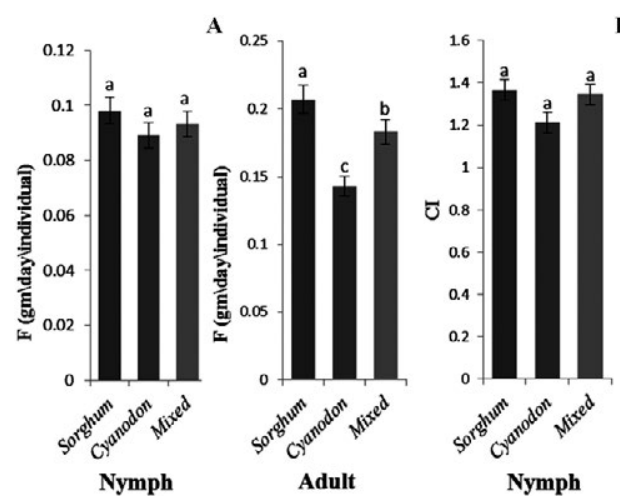

B 1.6

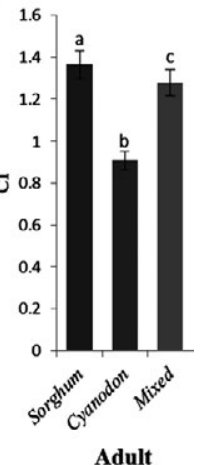

Fig. 1. A - Food Consumption (F); B - Consumption Index (CI) of nymph and adult Oxya hyla hyla reared on various host plants. Values are means $\pm \mathrm{SD}$. Columns marked with different letters are significantly different $(\mathrm{P}<0.05)$ (ANOVA followed by DMRT).

\section{Experimental setup}

One hundred one day old nymphs were freeze killed and dried in a hot air oven at $40^{\circ} \mathrm{C}$ until their weight remained constant. Then the mean dry weight of one day old individuals was calculated and used as the "standard". A further 270 nymphs were kept in groups of 30 individual in each of 9 transparent plastic jars, each measuring $11 \times 11 \times 26 \mathrm{~cm}$ (i.e. $3146 \mathrm{~cm}^{3}$ ). The size of jar was based on the results of Das et al. (2009) study, which indicates that the space required for rearing 25 adults of $O$. fuscovittata is $10 \times 10 \times 25 \mathrm{~cm}\left(\right.$ or $\left.2500 \mathrm{~cm}^{3}\right)$. Fine freshly washed and sterilized sand was spread over the floor and regularly sprinkled with water to keep it moist. Three groups of three jars were used for rearing the nymphs. In the jars of the first group they were reared on $S$. halepense, in the second on $C$. dactylon and in the third an equal mixture of $S$. halepense and $C$. dactylon. Fresh material of both the grasses was weighed and offered to the insects and every $24 \mathrm{~h}$ any uneaten grass removed and its dry weight determined. Adults were reared in the same sized plastic jars with 20 individual in each.

\section{Parameters measured}

Duration of the nymphal and adult stages was measured in days. Mortality was calculated as the percentage of the nymphs that died before reaching the adult stage.

Food consumption and utilization was calculated using the method of Waldbauer (1968) and De Silva \& Anderson (1998). Insects were provided with definite quantities of freshly washed food plants and any uneaten food was separated from the faeces, dried and weighed. A fresh sample of food (aliquot) was weighed and its weight $24 \mathrm{~h}$ later was used to determine the moisture loss from the food over this period. The dry weight in grams of food consumed $(\mathrm{F})$ was calculated taking into consideration the loss of moisture and dry weight of uneaten food using the formula developed by Waldbauer (1968):

$\mathrm{F}=\{(1-\mathrm{A}) / 2\} \times\{\mathrm{W}-\mathrm{L}(1+\mathrm{B})\}$

where $\mathrm{F}=$ dry weight of food consumed, $\mathrm{W}=$ fresh weight of food provided, $\mathrm{L}=$ dry weight of uneaten food, $\mathrm{A}=$ initial weight of the aliquot, $\mathrm{B}=$ final weight of the aliquot.

Consumption index (CI) and efficiency of conversion index (ECI) were calculated for nymphs and adults separately. Growth was measured in terms of growth rate (GR), specific growth rate (\% SGR) and average daily growth (\% ADG). The dry weights are for groups of insects and were used to calculate the change in the dry weight of individuals.
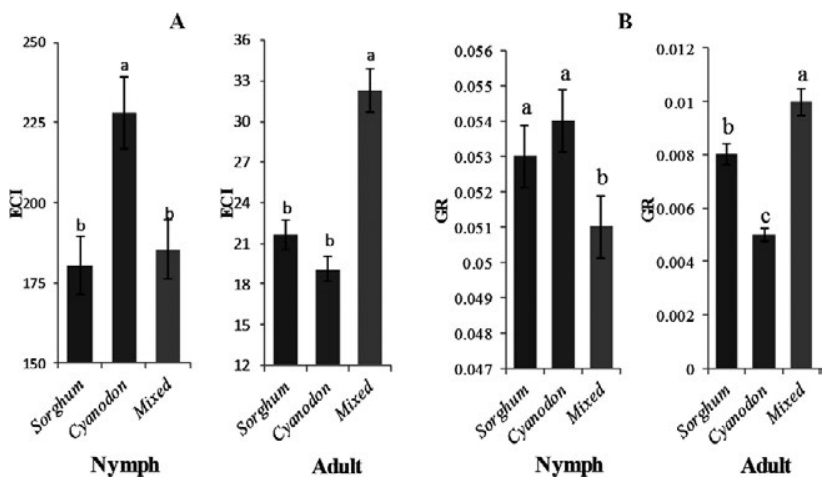

Fig. 2. A - Efficiency of Conversion Index (ECI); B - Growth Rate (GR) of nymph and adult Oxya hyla hyla reared on various host plants. Values are means $\pm \mathrm{SD}$. Columns marked with different letters are significantly different $(\mathrm{P}<0.05)$ (ANOVA followed by DMRT).

Consumption Index $(\mathrm{CI})=\mathrm{F} /\left(\mathrm{T} \times \mathrm{W}_{\mathrm{m}}\right)$

Efficiency of conversion of ingested food $(\mathrm{ECI})=\left(\mathrm{Wt}_{2}-\mathrm{Wt}_{1} / \mathrm{F}\right) \times 100$ Growth Rate $(\mathrm{GR})=\left(\mathrm{Wt}_{2}-\mathrm{Wt}_{1}\right) /\left(\mathrm{T} \times \mathrm{W}_{\mathrm{m}}\right)$

Specific Growth Rate $(\% \mathrm{SGR})=\left[\left(\log \mathrm{Wt}_{2}-\log \mathrm{Wt}_{1}\right) \times 100\right] / \mathrm{T}$

Average Daily Growth $(\% \mathrm{ADG})=\left(\mathrm{Wt}_{2}-\mathrm{Wt}_{1}\right) \times 100 /\left(\mathrm{Wt}_{1} \times \mathrm{T}\right)$

where $\mathrm{F}=$ dry weight of food consumed, $\mathrm{T}=$ duration of feeding period (in days), $\mathrm{W}_{\mathrm{m}}=$ mean dry weight of the insect, $\mathrm{Wt}_{1}=$ initial dry weight of the insect, $\mathrm{Wt}_{2}=$ final dry weight of the insect.

\section{Statistical analysis}

Values presented are means $\pm \mathrm{SD}$. A one-way analysis of variance (ANOVA) was used to compare the values obtained for the different parameters using Microsoft excel 2007 software. Duncan's multiple range tests (DMRT) of the results for each were used to determine whether the mean values differed significantly. All the analyses were done using Microsoft excel 2007 software.

\section{RESULTS}

\section{Food consumption and utilization}

The results of rearing nymphs of $O$. hyla hyla on S. halepense, C. dactylon and an equal mixture of these two plants revealed that nymphs in these three groups did not differ significantly $(p<0.05)$ in their food consumption and consumption index. However, comparison of the mean values revealed that nymphs of $O$. hyla hyla fed on $C$. dactylon consumed least food and had the lowest consumption index (CI) (Fig. 1A, B) but the best ef-
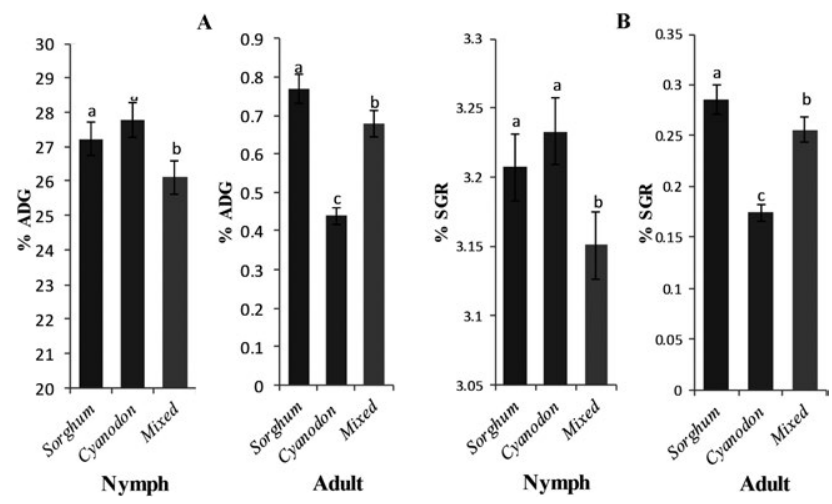

Fig. 3. A - Average Daily Growth (\% ADG); B - Specific Growth Rate (\% SGR) of nymph and adult Oxya hyla hyla reared on various host plants. Values are means $\pm \mathrm{SD}$. Columns marked with different letters are significantly different $(\mathrm{P}<0.05)(\mathrm{ANO}-$ VA followed by DMRT). 


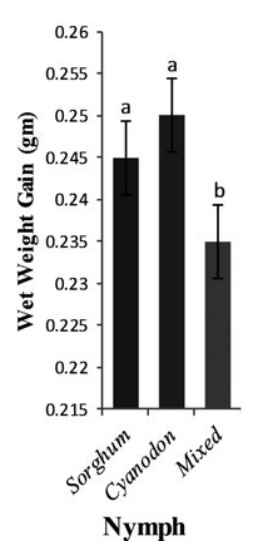

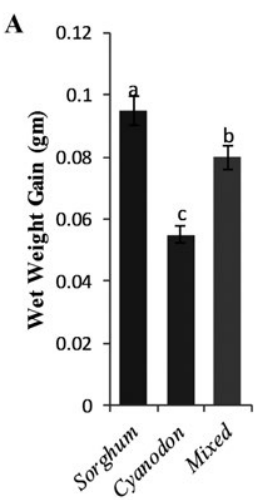

Adult

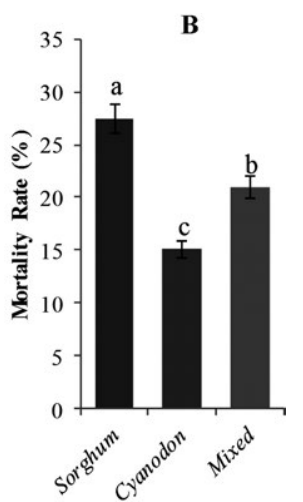

Food Plants

Fig. 4. A - Wet Weight Gain of nymph and adult; B - Percentage mortality of Oxya hyla hyla reared on various host plants. Values are means $\pm \mathrm{SD}$. Columns marked with different letters are significantly different $(\mathrm{P}<0.05)$ (ANOVA followed by DMRT).

ficiency of converting ingested food into body mass (ECI) (Fig 2A). The nymphs fed on $S$. halepense consumed the most food and had the highest consumption index, followed by those fed a mixed plant diet.

The three groups of adult $O$. hyla hyla differed significantly in the amount of food they consumed and their consumption indices $(\mathrm{p}<0.05)$. Those fed on $S$. halepense consumed the most food and had the highest consumption index (Fig. 1A, B) but lowest ECI. Those fed the mixed plant diet had the highest ECI (Fig. 2A) followed by those fed on $S$. halepense. The group fed on $C$. dactylon performed worst (Fig. 2A).

\section{Effect of the different food plants on the growth of nymphs and adults}

Based on the \% ADG and \% SGR nymphs grew faster than adults. However, there were no significant differences in the growth (GR) of the nymphs fed on S. halepense and C. dactylon. Nymphs fed on C. dactylon had the best and those fed on a mixed plant diet the worst growth rate (Fig. 2B). Adults fed on C. dactylon grew significantly less than those fed on $S$. halepense and a mixed plant diet (Fig. 2B).

Based on $\%$ ADG and $\%$ SGR nymphs grew faster when reared on $C$. dactylon than on $S$. halepense and faster on $S$. halepense than on a mixed plant diet (Fig. 3A, B). During their development (34 days) the nymphs of $O$. hyla hyla gained in wet weight by a similar amount of $0.250 \mathrm{~g}$ when reared on $C$. dactylon and $0.245 \mathrm{~g}$ on $S$. halepense (Fig. 4A). The wet weight gain of the adults was less and best when reared on $S$. halepense followed by on a mixed plant diet.

\section{Effect of the different diets on the duration of nymphal development, adult life span and mortality}

Those fed on S. halepense took the longest time (37.33 days) to complete their nymphal development (Fig. 5) and suffered the highest mortality (27.462 \pm 1.198$)$ (Fig. 4B) compared to those fed on the other two diets. The shortest duration of nymphal development of $33.13 \pm 1.72$ days was recorded for the group fed the mixture of the two plants followed by those fed on $C$. dactylon (35.06 \pm 1.58 days) (Fig. 5). Nymphal mortality was lowest $(15.07 \pm 1.89 \%)$ in the group fed on C. dactylon (Fig. 4B). The adult life span of the males and females differed with the females living longer than the males. Adult life spans of both male and female were significantly longer, $41.06 \pm 2.63$ and $50.46 \pm 1.64$ days, respectively, when fed on $C$. dactylon, followed by the mixed diet and $S$. halepense (Fig. 5).
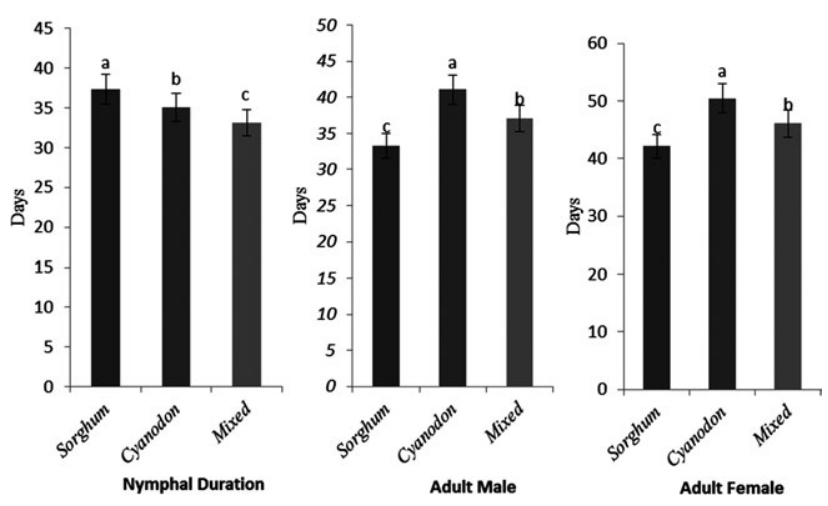

Fig. 5. Duration of nymphal stage and life span of adult male and female Oxya hyla hyla reared on various host plants. Values are means $\pm \mathrm{SD}$. Columns marked with different letters are significantly different $(\mathrm{P}<0.05)$ (ANOVA followed by DMRT).

\section{DISCUSSION}

The survival and growth of an insect is dependent on the quality of its food (Sanjayan \& Murgun, 1987; Ganguly et al., 2010; Das et al., 2012b). During its development an animal requires nutrients (i.e., protein, carbohydrate, fat, micro-nutrient and water) for growth, reproduction and other metabolic activities. Moreover, animals can regulate feeding in two ways either by regulating the amount of a particular food eaten or selecting among alternative foods (Simpson \& Raubenheimer, 1993). According to Behmer (2009), insects balance their nutritional requirements in three ways. At first, it consumes food until it achieves its requirements for carbohydrate while still in deficit in terms of protein. Secondly, it consumes food to fulfil its requirement for protein. The third option is to compromise and adopt some intermediate feeding strategy. Thus, herbivorous insects must comprise when foods are nutritionally imbalanced and there are conflicts between the mechanisms controlling the intake of nutrients (Simpson \& Raubenheimer, 1993).

The present study determined the consumption and utilization of food for growth and the life span of a multivoltine grasshopper, Oxya hyla hyla, reared on different food plants belonging to the family Poaceae viz. Cynodon dactylon and Sorghum halepense, in order to find a suitable plant for the mass rearing of this grasshopper. $O$. hyla hyla is a multivoltine, polyphagous grasshopper and a common pest of rice in India. Das \& Ray (2013) studied the feeding ecology of this species and list 16 host plants of which $C$. dactylon is the most preferred in the north eastern part of India. Das et al. (2012a) report the optimum temperature and photoperiod conditions for its mass production and suggest this species is a potential candidate for mass culture. Das et al. (2012b) report that the young nymphs of $O$. hyla hyla prefer to feed on soft green grasses (D. aegyptium) and after the $3^{\text {rd }}$ instar on $B$. mutica. Proper nymphal development is crucial for the survival of grasshopper populations and biomass production. The ability of nymphs to ingest and convert food to utilizable energy ensures an optimal growth rate, body weight and increases its probability of surviving to adulthood. In the present study, nymphs of $O$. hyla hyla did not differ significantly $(\mathrm{p}<0.05)$ in the pattern in their consumption of food when reared on C. dactylon, S. halepense and a mixed plant diet. However, when mean values of food consumption were compared the highest food consumption was recorded in the group fed on S. halepense. The lowest quantity of food consumed and the highest ECI were recorded for the nymphs reared on $C$. dactylon. This indicates that the efficiency of utilization of the food by nymphs of $O$. hyla hyla was best when they fed on C. dactylon. 
Zheng et al. (1993) and Ganguly et al. (2010) report that larval growth and development are dependent on the quality of the food plant. Growth of $O$. hyla hyla (GR, \% ADG and \% SGR) and its wet weight gain during nymphal development were significantly greater $(\mathrm{p}<0.05)$ when fed on $C$. dactylon than the other two diets.

Short nymphal duration increases the chance of survival to adulthood and reduces the amount of food required. For a short nymphal development an adequate and suitable diet is required (Price et al., 1980). Fanny et al. (1999) report that in Oxya nitidula the shortest nymphal periods is recorded when it is reared on Panicum maximum. Similarly Ganguly et al. (2013) report duration of nymphal development is shortest for $S$. prasiniferum prasiniferum fed on $S$. halepense and Oedaleus abruptus fed on T. aestivum. In the present study, the shortest duration of nymphal development $(33.133 \pm 1.727$ days $)$ was for the group fed on the mixed plant diet followed by the insignificantly longer $35.067 \pm 1.580$ days recorded for the group fed on $C$. dactylon. However, mortality was significantly less, $15.07 \pm 1.89 \%$ in the group fed on $C$. dactylon compared to the other two groups. Based on the duration of nymphal development and mortality, C. dactylon is the better food plant for rearing nymphs of $O$. hyla hyla.

According to Ganguly et al. (2010) O. fuscovittata, another pest of rice, grows and reproduces best when reared on $S$. halepense and worst when reared on Oryza sativa. Authors are of the opinion that rice is not a suitable host plant for the initial stages of this species, which prefer soft grasses. In our study, adult $O$. hyla hyla consumed more and had a lower ECI when fed on $S$. halepense and consumed less and had a higher ECI when fed on a mixed plant diet. It is likely that grasshoppers that encounter plants low in critically needed substances do not eat them (Raubenheimer \& Simpson, 1990) but if they have no choice they might consume greater amount of a lower grade food to compensate for its low nutritional value, whereas if high quality food plants are available they consume smaller quantities of these plants. The adults grew more slowly than the nymphs because they invested most of the energy they obtained from their food in reproduction. Growth and survival determine the amount of biomass produced. Growth (GR, \% ADG and \% SGR and wet weight gain) of adult grasshoppers was greatest when fed on $S$. halepense followed by a mixed plant diet. Though ECI was less when fed on $S$. halepense the grasshopper consumed more food to compensate for its poor quality and as a consequence grew faster and produced a greater biomass. A long adult life span indicates good health and may result in the production of more egg pods. Adults of $O$. hyla hyla fed on $C$. dactylon lived the longest but gained less weight. This study clearly showed that for mass culture and biomass production of Oxya hyla hyla, Cyanodon dactylon is the best food plant for rearing nymphs and Sorghum halepense the best for rearing adults.

ACKNOWLEDGEMENTS. We thank the Head of the Department of Zoology, Visva-Bharati University for providing the laboratory and infrastructural facilities and the University Grants Commission (UGC), Government of India for providing financial support in the form of a Major research project F. no. 43358/2011(SR).

\section{REFERENCES}

Abdel Rahman K.M. 2001: Food consumption and utilization of the grasshopper Chrotogonus lugubris blanchard (Orthoptera, Acridoidea, Pyrgomorphidae) and its effect on the egg deposition. - J. Central Eur. Agric. 2: 263-270.
Anand H., Das S., Ganguly A. \& Halder P. 2008a: Biomass production of Acridids as possible animal feed supplement. $-J$. Environ. Sociobiol. 5: 181-190.

Anand H., Das S., Ganguly A. \& Halder P. 2008b: Potential value of acridids as high protein supplement for poultry feed. Int. J. Poult. Sci. 7: 722-725.

Ananthakrishnan T.N., Dheelipan K. \& Padmanabhan B. 1985: Behavioral responses in terms of feeding and reproduction in some grasshoppers (Orthoptera: Insecta). - Proc. Ind. Acad. Sci. (Anim. Sci.) 94: 443-461.

BEHMER S.T. 2009: Insect herbivore nutrient regulation. - Annu. Rev. Entomol. 54: 165-187.

DAS M. \& RAY D.C. 2013: An alternative host preference study of Oxya hyla hyla (Orthoptera: Acrididae) - a non-insecticidal method of pest management. - Ind. J. Appl. Res. 6: 315-316.

Das M., Ganguly A. \& Halder P. 2009: Space requirement for mass rearing of two common Indian acridid adults (Orthoptera: Acrididae) in laboratory condition. - Am. Euras. J. Agric. Environ. Sci. 6: 313-316.

Das M., Ganguly A. \& Halder P. 2012a: Determination of optimum temperature and photoperiod for mass production of Oxya hyla hyla (Serville). — Turk. J. Zool. 36: 329-339.

Das M., Ganguly A. \& Halder P. 2012b: Annual biomass production of two acridids (Orthoptera: Acrididae) as alternative food for poultry. - Spanish J. Agric. Res. 10: 671-680.

DeFoliart G.R. 1992: Insects as human food. - Crop Prot. 11: 395-399.

De Silva S.S. \& Anderson A. 1998: Fish Nutrition in Aquaculture. Chapman \& Hall, London, 319 pp.

Fanny I.P., Ravikumar T., Muralirangan M.C. \& Sanjay K.P. 1999: Influence of host plants on the duration of post-embryonic development and food utilisation of Oxyanitidula (Walker) (Orthoptera: Acrididae). - J. Orthopt. Res. 8: 119-124.

Ganguly A., Chakravorty R. \& Sarkar A. 2010: Johnson grass [Sorghum halepense (L.) Pers.]: a potential food plant for attaining higher grasshopper biomass in Acridid farms. Philipp. Agric. Scientist 93: 329-336.

Ganguly A., Chakraborty R., Das M., Gupta M., Mandal D.K., Haldar P., Ramos-Elorduy J. \& Pino Moreno J.M. 2013: A preliminary study on the estimation of nutrients and anti-nutrients in Oedaleus abruptus (Thunberg) (Orthoptera: Acrididae). - Int. J. Nutr. Metab. 5(3): 50-65.

GunN D.L. 1960: The biological background of locust control. Annu. Rev. Entomol. 5: 279-300.

Haldar P., Bhandari K.P. \& Nath S. 1995: Observation on food preferences of an Indian grasshopper Acrida exaltata (Walker) (Orthoptera: Acrididae: Acridinae). - J. Orthopt. Res. 4: $57-59$.

Haldar P., Das A. \& GuPTA R.K. 1998: A laboratory base study on farming of an Indian grasshopper Oxya fuscovittata (Marschall) (Orthoptera: Acrididae). — J. Orthopt. Res. 8: 93-97.

LEDGER J. 1987: The eighth plague returneth! The locusts are coming. - Afr. Wildlife 41: 201-210.

Lomer C.J., Bateman P., Johnson D.L., Langewald J. \& Thomas M. 2001: Biological control of locusts and grasshoppers. Annu. Rev. Entomol. 46: 667-702.

Macfarlane J.H. \& Thorsteinson A.J. 1980: Development and survival of the two striped grasshopper Melanoplus bivittatus (Say) (Orthoptera: Acrididae) on various single and multiple plant diets. - Acrida 9: 63-76.

Price P.W., Boutom C.E., Gross P., McPheron B.A., Thompson J.N. \& WeIs A.E. 1980: Interaction among three tropical levels: influence of plants on interaction between insect herbivores and natural enemies. - Annu. Rev. Ecol. Syst. 11: 41-65. 
RAmOS-EloRduY J. 1997: Insects: A sustainable source of food? - Ecol. Food Nutr. 36: 247-276.

Ramos-Elorduy J., Morales De L.J., Pino J.M. \& Nieto Z. 1988 Contenido de tiamina, riboflavina y niacina en algunos comestibles de Mexico. - Rev. Tecnol. Aliment. 23: 21.

RAUBENHEImER D. \& Simpson S.J. 1990: The effect of simultaneous variation in protein, digestibile carbohydrate and tannic acid on the feeding behavior of larval Locusta migratoria (L.) and Schistocerca gregaria (Forskal). I. Short-term studies. Physiol. Entomol. 5: 219-223.

SAnJayan K.P. \& Murgun K. 1987: Nutritional influence on the growth and reproduction in two species of acridids (Orthoptera: Insecta). — Proc. Acad. Sci. (Anim. Sci.) 96: 229-237.

Simpson S.J. \& Raubenheimer D. 1993: A multi-level analysis of feeding behavior: the geometry of nutritional decisions. Phil. Trans. R. Soc. Lond. (B) 342: 381-402.
Ueckert D.N., Yang S.P. \& Albin R.C. 1972: Biological value of rangeland grasshoppers as a protein concentrate. - J. Ecol. Entomol. 65: 1286-1288.

Uvarov B. 1966: A Handbook of General Acridology. Cambridge University Press, Cambridge, $181 \mathrm{pp}$.

WALDBAUER G.P. 1968: The consumption and utilization of food by insects. - Adv. Insect Physiol. 5: 229-288.

Wang D., Shao-Wei Z., Chuan-Xi Z., Zhang Q. \& Chen H. 2007: Nutritional value of the Chinese grasshopper Acrida cineria (Thunberg) for broilers. - Anim. Feed Sci. Technol. 135: 66-74.

Zheng Y., Hagen K.M., DaAne K.M. \& Mittler T.E. 1993: Influence of larval dietary supply on the food consumption, food utilization efficiency, growth and development of the lacewing (Chrysoperla carnea). — Entomol. Exp. Appl. 67: 9-14.

Received August 27, 2013; revised and accepted January 28, 2014 Prepublished online April 23, 2014 